\title{
CAN RESPONSIBLE LEADERSHIP AFFECT WORK-LIFE BALANCE/IMBALANCE? A STUDY ON FEMALE PHARMACISTS IN EGYPTIAN PUBLIC HOSPITALS
}

\author{
Mohamed, Mousa \\ Estonian Business School, Estonia, Mohamed.mousa@ebs.ee
}

\begin{abstract}
As a result of the scandals in organizations like Enron, Arthur Anderson and WorldCom in addition to the 2008 global economic crisis, management scholars and practitioners have started to ask about the adequacy of current styles of leadership. Many management academic experts have realized that focusing only on maximizing shareholder profit is no longer acceptable as a sole business target. This has fostered the emergence of responsible leadership in the last 7 years as an attempt to fulfill both shareholders and stakeholders well-being.

Over the past two decades there has been a growing awareness of labor market participation and feminist active lobbying, and the concept "work- life balance" has come to be considered a buzzword in both management and organization studies. Moreover, the concept has also gained a rising significance owing to its positive correlation with individual and organizational performance.

This study focuses on public hospital in Menoufia province (Egypt) and investigates the effect of responsible leadership dimensions (aggregate of virtues, stakeholder involvement, model of leader's role and principles of ethical values) on forms of work-life balance of pharmacists (time-based balance/imbalance, strain-based balance/imbalance and behavior-based balance/imbalance). Having collected and analyzed 230 questionnaire forms and used hierarchical regression analysis, the researcher found that only the aggregate of virtues is not considered a significant statistical predictor of the three forms of work-life balance/ imbalance, whereas the other 3 dimensions of responsible leadership were found to be strong determinants of the 3 forms of work-life balance/ imbalance.
\end{abstract}

KEYWORDS - responsible leadership; work- life balance/imbalance; time- based balance/imbalance; strain- based balance/ imbalance; behavior-based balance/imbalance; Egypt

\section{INTRODUCTION}

Leadership style is an effective mechanism that prompts employees to innovate, business models to be checked and updated, work problems to be discovered and managed and finally organizations to be driven in order to survive and prosper. However, leadership today is undergoing a transitional stage (Erkutlue and Chafra, 2016). The scandals in organization like Enron, Tyco and WorldCom along with the 2008 global economic crisis the world witnessed have raised questioned about the relevance and adequacy of the known leadership styles (Inglehart, 2008). The role and accountability of business community leaders are also put to question. In this light, many business leaders and academic experts have realized that maximizing businesses profits cannot be the only target (Wade, 2006). And thus, any business attempt to maximize profit should be accompanied by a considerable concern for achieving the well-being of the environment that the firm operates in, the welfare of internal and external stakeholders the firm serves and the wisdom the firm employs when dealing with its staff (Hymavathi et al., 2015). This creates a space for what academicians choose to label "responsible leadership" which urges organizations' leaders to maintain a noticeable commitment towards alleviating poverty, supporting peace, promoting freedom and safeguarding human rights in the communities their organizations serve (Bonoli, 2005, Carrasco, 2007, Avram \& Kunhe, 2008, Antunes \& Franco, 2016). Ciculla, (2004), De Hoogh \& Den Hartog (2008), Earley (1989) and Eva \& Sendjaya (2013) indicate that responsible leaders constantly disseminate the values of virtue, wisdom, empathy and sympathy for the betterment of their societies (Holt, 2006, Maak \& Pless, 2008, Morland, 2015). That's why, the studies of (Fishbein \& Ajzen, 1975, Pless, 2007, Maak\& Pless, 2009, Pless \& Maak, 2011, Nonet et al., 2016) elaborates that social responsibility is the main challenge facing responsible leaders nowadays. Leadership research is no longer limited to leader/followers relationship but instead has expanded to cover leader-stakeholder relationship. It is concerned with various ways that stakeholders perceive such relationship and that responsible leaders seek to support and maintain that relationship (Tran et al., 2016).

Over the last two decades, work-life balance has become a buzzword in various academic disciplines like human resources management, cultural diversity management, organizational communication, and organizational behavior (Andersen, 2009, Anxo et al., 2013). Due to the growing awareness of demographic changes, labor market participation, feminist active lobbying and paid employment, the concept has found a place in countries' public policies (Hennig et al., 2012). Therefore, many public and private employers have provided 35 
paid maternity and on-site childcare services as a part of their responsibilities towards employees (Emslie and Hunt, 2009). However, with an increase in employee's average income and the socio-cultural shifts they experience, employees are calling for far more demands that employers have to fulfill (Lim et al., 2012).

Avgar et al. (2011) elaborate that work-life balance is no longer considered a welfare but an effective dynamic an organization should adopt to retain its talents. The same study found a negative relationship between the existence of effective work-life policies and employees' turnover intentions. Parkes and Langford (2008) indicate that the importance of work-life balance stems from its positive impact on both individual and organizational performance, whereas Nelson et al. (2012) found a positive linkage with job satisfaction. Moreover, Shoekand and Priyanka (2013) report a positive correlation between work- life balance dimensions and an organization's ability to motivate its employees.

Balancing employees' work-life is a main challenge different organizations have to manage. This may justify why fortune magazine often shows respect to organizations that assist their employees in achieving such intended balance (Muse et al., 2008). In this regard, Rogers and Rogers (1989) define family friendly organizations as organizations that seek to enable employees in achieving a balance between work and family life, whereas Redmond et al. (2006) compare work-life balance as organizational policies that intend to support employees in balancing work and family life.

As pharmacists, Egyptian females who work in governmental hospitals complain mainly about low salaries and long work hours (Mousa, 2017, Mousa \& Abdelgaffar, 2017). Mousa (2017) reported that pharmacists, regardless of their gender, are not allowed to ask for vacations due to the complete dependence on them to handle remedies to patients. Moreover, the same previously mentioned study indicated that the main challenges facing Egyptian female pharmacists is that they are required to work an uninterrupted 12 hours' night or day shift (called Nobatshiya). This means no attention to these pharmacists' families, fatigue, and morale. Some female pharmacists mentioned that they have to do these night or day shifts even during official national and religious vacations. On a voluntary basis, many male pharmacists volunteer to work in place of females on such days such as the feasts. Accordingly, this research seeks to focus solely on public hospitals, Menoufia province, Egypt and to fill a gap in the management literature by identifying the effect of responsible leadership on work- life balance/ imbalance among female pharmacists work there. The authors start by providing a theoretical background for responsible leadership, work life balance/imbalance and end their theoretical discussion by formulating their hypotheses. Subsequently, the research methodology is presented, in which the authors elaborate their research plan and present the reliability analysis for their variables besides illustrating the profiles of their respondents. Finally, the results are presented and discussed, and the conclusions also offer suggestions for future research.

\section{LITERATURE REVIEW}

\subsection{Responsible leadership}

As indicated earlier, responsible leadership is still in its infancy, and a shortage in the research addressing it is markedly noted (Maak and Pless, 2006). Moreover, Waldman and Galvin (2008) have indicated that only after the demise of Enron and Arthur Anderson and the 2008 world economic crisis have the deficiencies of current leadership practices been discovered. This prompted the emergence of responsible leadership as a dynamic to initiate the social and political responsibility of businesses in addition to the political one. Furthermore, the concept "responsible leadership" itself is still confronting many challenges to be defined and adopted. Preez and Zyl (2015) have elaborated that to fulfill social obligations; businesses have to coordinate with different governments to achieve countries' stated goals of eradicated poverty, developed education, and accelerated economic growth among many other different goals. This matter may not be applicable in all countries due to the burden of coordinating with governments in addition to the bureaucracy of some governmental systems. Another main challenge facing responsible leaders is how to balance the trade-off between maximizing shareholders' profit and caring about the wellbeing of both shareholders and businesses they serve (Voegtlin, 2011, Pless \& Maak, 2012, Morland, 2015). Pless and Maak (2011) have investigated what makes leaders responsible and how responsible leaders can be developed. On the other hand, Morgeson et al. (2013) indicate that both human resources management and organizational psychology experts can address the cultural challenge of leadership and determine the main competencies leaders need in order to be effective in fulfilling their societal responsibility. This can be undertaken when businesses start to carefully understand that adoption of responsible leadership may provide an edge for creativity, innovation and subsequently competitive advantages (Preez and Zyl, 2015).

The current literature of responsible leadership has no generally accepted definition for responsible leadership. Maak and Pless (2006, p. 103) have defined it as "a relational and ethical phenomenon, which occurs in social processes of interaction with those who affect or are affected by leadership and have a stake in the purpose and vision of the leadership relationship". Apparently, this definition is derived from the following two theories:

- First, agency theory maintains that the agent (business leaders) accepts to act on principal's (shareholders) behalf and to have the authority of decision making. According to this theory, maximizing shareholders' profits is the sole responsibility of business leaders, and there is no considerable space to fulfill any societal obligations and ethical customs (Friedman and Friedman, 2002).

- Second, stakeholder theory shows a concern of fulfilling the various needs of in and out stakeholders. This is constantly paid attention to by the business leaders besides maximizing shareholders' financial profits. This theory justifies why responsible leaders pay attention to the societal open-ended priorities like eliminating poverty, safeguarding human rights and other socio-environmental concerns (Maak and Pless, 2006).

As illustrated above, a responsible leader acts correctly on behalf of both shareholders and stakeholders. That's why he or she should have all means, capabilities, resources and authority required to attain as much benefits as possible for all parties involved (Cameron, 2011). Hymavathi et al. (2015) have indicated that responsible leadership is a social phenomenon guided by moral standards. The thought that falls in line with Martin Luther King's question "what are you doing for others?". Given what has preceded, responsible leaders should listen to different views and work closely with not only people and departments within their organizations but also with various external stakeholders like consumer groups,36 
governmental officials and even environmentalists (Cunha et al., 2007).

\subsection{Work-life balance}

Although Murphy and Doherty (2011) indicate that economic recession and tendency to reduce costs are considered the main reasons for the emergence of flexible work policies especially in Europe, Gregory et al. (2013) consider work-life balance as an economic mechanism to raise employment rate. Moreover, Bonoli (2005) and Andersen (2009) illustrate that supporting individuals to reconcile work and family obligations (e.g. paid employment with childcare and/ or elder care) is a priority for countries that seek welfare for its citizens. However, earlier research on work-life balance was conducted after 1990 to address, on the one hand, the importance of introducing worklife balance policies into the corporate workplace (Lee, 2005), and on the other hand, the relationship between work-life policies and some individual behavior practices like intentions to leave, rate of turnover, level of absenteeism and employee performance (Kim, 2012).

Anxo et al. (2013) highlight that designing and adopting worklife policies in a specific work setting entail an intersection for the following characteristics:

- Demographic characteristics (gender, age, partner's response of collaboration).

- Workplace characteristics (organizational culture, leaders' supportive tendencies, workload).

- Socio-economic characteristics (country economic situation, welfare policies).

As previously mentioned in the introduction, the importance of work-life balance stems from its ability to shape an employee's psychological well- being (Clark, 2000). Furthermore, in the organizational context, work-life policies have a positive relationship with employee's loyalty, performance and job satisfaction (Nelson et al., 1990; Cegarra- Leiva et al., 2012; Carlson et al., 2008). Also, these policies are negatively correlated with an employee's intention to leave, turnover, absenteeism and poor performance (Froue et al., 1997; Avgar et al., 2011, Mousa \& Alas, 2016, Mousa, 2017). It is clearly noted that the majority if not all of the research on work-life balance has been conducted in western countries, in which individualistic interest dominates life and employees prioritize their personal goals and constantly aim to attain them usually before the goals of the organization to which they belong (Earley, 1989). Given what has proceeded, it is preferable to clarify that work-life balance has stemmed its roots from the following two theories:

- Attitude- behavior theory: reflects the positive or negative attitudes an individual perceives in any organizational setting which in turn translated into the positive or negative behavior an individual undertakes with or against this setting (Fishbein and Ajzen, 1975). Concerning the topic of work-life balance, employees constantly exert their full capacity towards achieving the goals of the organization upon sensing organizational support in reconciling their family obligations.

- Social exchange theory: is one of the most important theories in explaining workplace behavior. Therefore, it can be touched on in various organizational and managerial topics such as psychological contract, organizational justice, board independence and responsible leadership (Cropanzano and Mitchell, 2005). It reflects "those voluntary actions of actors that are motivated by the returns they are expected to elicit from other" (Blan, 1964, P. 91). Fao and Fao (1974) identifies that love, status, money, information, goods and services are considered the six types of resources included in employer-employee relationship. According to this theory, when an employer cares about his/her employee, and this employee perceives fair treatment from his/her employer, the later subsequently does his/her best to fulfill organizational objectives, and he/she constantly has a positive attitude towards his employer.

Despite the various work arrangements (e.g. part- time work, job sharing, career break, compressed hours and etc.) an organization can undertake to assist employees in juggling their non-work activities, Drew and Murtagh (2005) have pointed out that only 17 percent of senior managers employ some work arrangements to reduce their working hours and create time for non-work responsibilities. Apparently, this happens despite the advanced information technology and communication means businesses has applied over the past three decades (Eikof et al., 2007). However, a correlation between presenteism and financial incentives is considered the main reason for managers' unwillingness to benefit from communication technology advancement and various work arrangements (Elloy and Smith, 2003).

Worthy to mention is the poor utilization of family friendly policies pertaining, in some settings, to organizational culture that considers long work hours as an indicator of employee's organizational commitment (Drew and Daverth, 2009). However, there is a growing tendency to shift from long hours to a results-focused approach when measuring employee's level of performance as illustrated by Drew et al. (2003). Feminist advocators reflect that women currently not only perform double effort but also spend longer time at the workplace in their attempt to find a place in male-dominated societies (Straub, 2007, Mousa\&Alas, 2016). Furthermore, Drew et al. (2003) clarify that the situation is even worse when having limited number of women at organizational board or management level. This may be considered another struggle for the poor adoption of family friendly initiatives in some organizational setting.

In the Egyptian society, Hofstede (1980) identifies four main characteristics constituting the Egyptian culture:

- Power distance: reflects the tendency of Egyptians to accept their leader's authority, whatever the decisions he or she makes.

- Uncertainty avoidance: reflects Egyptian tendency to resist any potential change whatever its kind (political, social and etc.)

- Individualism: reflects the strong power Egyptian families have in shaping individual's behavior.

- Masculinity: reflects the superior level men have in Egyptian society and that to a certain extent stems from Islamic religious values.

What preceded illustrates the struggle Egyptian women face not only at a societal level but also as an employee. This also may justify why the UN report (2007) and Alas \& Mousa (2016) mention that Egyptian women face many forms of discrimination and recommended prompt efforts to alleviate them.

\subsection{Responsible leadership and work-life balance}

Eikhof et al. (2007) affirm that adopting family friendly policies in organizational setting guarantee workplace 37 
harmony and subsequently employee's work-life balance. Fu and Shaffer (2001) and Carnicer et al. (2003) identify the following three forms of work-life balance/ imbalance that an employee may experience.

- Time-based balance/ imbalance: reflects the extent to which long work hours may affect non-work devoted time, and subsequently imbalance arises between work and nonwork life.

- Strain-based balance/ imbalance: reflects the extent to which stress may arise as a result for employee's trial to reconcile work and non-work activities.

- Behavior based balance/ imbalance: reflects employee's sufferings that results from his inability to manage his behavior and balance his work and non-work activities.

Like ethical leadership, responsible leadership fosters both individual and organizational performance (Brown and Trevino, 2006). However, Chun (2005) indicates that the main roles of responsible leaders are building social networks with in- and- out stakeholders, listening to various view points, fulfilling societal responsible obligations besides differentiating between right and wrong. That's why the scope of responsible leadership is much broader than the ethical one which focuses only on leader-follower relationships (Pless \& Maak, 2012). To the best of author's knowledge, no previous attempts have been conducted to address the effect of responsible leadership dimensions on the three forms of work life balance/ imbalance. Accordingly, the following are the main hypotheses suggested by the author:

- H1: can responsible leadership dimensions (aggregate of virtues, stakeholders' involvement, principles of ethical values, model of leaders' roles) affect time-based work and non-work balance/ imbalance?

- H2: can responsible leadership dimensions (aggregate of virtues, stakeholders' involvement, principles of ethical values, model of leaders' roles) affect strain-based work and non-work balance/ imbalance?

- H3: can responsible leadership dimensions (aggregate of virtues, stakeholders' involvement, principles of ethical values, model of leaders' roles) affect behavior-based work and non-work balance/ imbalance?

\section{METHODOLOGY}

To design the conceptual framework of this is a quantitative study, the author reviewed many previous studies conducted on either responsible leadership or work-life balance. To the best of the author's knowledge, no previous studies have focused on investigating the effect of responsible leadership dimensions on work-life balance forms. This may derive from the fact that the topic of responsible leadership is still in its embryonic stage, and not so many scholars have paid attention to it. The study has been conducted on female pharmacists in Sadat city public hospitals in Menoufia (Egypt). Clearly, the focus on Sadat city public hospitals was not the main priority for the author of the present paper at the first stage of his research. The intention was to include all public hospitals in Menoufia province, which is one of 27 provinces in Egypt and to address as many female pharmacists as the author can but unfortunately, this was not the case as the managers of Menoufia province public hospitals did not accept to cooperate either for the lack of time or for the sensitivity of the topic. Some of them consider the topic as an exposure of the country's style of leadership and the level of freedom allowed. Noticeably, Sadat city public hospitals executives have reacted positively to the idea of data collection for this study.
As previously mentioned, the major problems facing Egyptian female pharmacists who work in public hospitals are working an uninterrupted basis for 12 hours and an inability to ask for any vacation even during national holidays (Mousa, 2017). Consequently, they are unable to fulfill any social obligations toward their families, constantly feel stressed to create time for even their rest, and eventually feel careless towards their work and often have the tendency to leave their positions. Addressing the effect of responsible leadership, which is based on the idea of fulfilling the main interests of both internal and external stakeholders without neglecting shareholders' profit. This means that work-life balance forms may shape a mutual benefit to be achieved for both the staff and the organizations.

The number of Egyptian pharmacists who work in public hospitals in the 27 Egyptian provinces is about 30000, 1400 of whom work in Menoufia province public hospitals. The present paper focuses only on female pharmacists. Four of these female pharmacists agreed to distribute and collect 350 questionnaire forms to their colleagues. 225 out of the 230 collected forms were valid for analysis.

As the author decided to rely on multiple regressions, an apriori Sample Size Calculator was used to determine the minimum required sample size on which the author can depend. Given the desired probability level (0.05), the number of predictors in the model (3), the anticipated effect size (minimum 0.079), and the desired statistical power (0.8), the minimum sample size the author can utilize is 99 questionnaire forms.

The fact that all public hospitals in Sadat city have 6 pharmaceutical departments (intensive care pharmaceutical department, external pharmaceutical department, liver disease pharmaceutical department, country support pharmaceutical department, national insurance pharmaceutical department and internal pharmaceutical department) has urged the author to employ stratified random sampling. Participants are classified into 6 homogenous subgroups to reduce bias and ensure valid representation. The procedures of distributing, following up and then collecting the distributed questionnaire forms extended for 4 weeks, and all questionnaire forms were distributed in Arabic to motivate the participants to respond and to ensure more accurate responses.

\subsection{Measures}

\subsubsection{Since research conducted on responsible leadership is still quite limited, there is no generally accepted model of responsible leadership.}

Accordingly, the author focused on the 4 dimensions (aggregate of virtues, stakeholders' involvement, model of leaders' roles and principles of ethical values) of responsible leadership developed by the qualitative study of Antunes and Franco (2016). Consequently, the following are the 4 sections of the qualitative form created by the author of this paper.

- $\quad$ aggregate of virtues

- My hospital cares about public-related aspects like education, health and poverty.

- My hospital differentiates between right and wrong.

- $\quad$ stakeholder involvement

- My organization involves in-and-out of organizations viewpoints when making decision.

- My hospital has long lasting relationships with various stakeholders.

- model of leaders' role

- My hospital respects diversity in and around it. 
- My hospital considers social responsibility as a part of organizational culture.

- $\quad$ principles of ethical values

○ I feel my managers are sincere when dealing with in and out stakeholders.

- My organization accepts critiques from in and out hospital stakeholders.

The following table (Table 1) presents the reliability analysis for responsible leadership challenges using Cronbach's alpha.

Table 1. Reliability Analysis (responsible leadership dimensions)

\begin{tabular}{|c|c|c|}
\hline Scale name & $\begin{array}{c}\text { Number of } \\
\text { items }\end{array}$ & $\begin{array}{c}\text { Coefficient } \\
\text { alpha values }\end{array}$ \\
\hline Responsible leadership dimensions & 8 & .795 \\
\hline Aggregate of virtues & 2 & .808 \\
\hline Stakeholder involvement & 2 & .810 \\
\hline Model of leader's role & 2 & .801 \\
\hline Principles of ethical values & 2 & .791 \\
\hline
\end{tabular}

\subsubsection{Work-life balance/ imbalance:}

Despite the various approaches to work-life balance, the present study focuses on the 3 forms of work- life balance (time- based balance/imbalance, strain- based balance/ imbalance and behavior- based balance/ imbalance) identified by Fu and Shaffer (2001) and Carnicer et al. (2003). These 3 forms represent the main challenges of work/ non- work activities applicable to senior or management level (Murphy and Doherty, 2011). The pharmacists in the chosen hospital are supervised by only one pharmaceutical departments manager besides the executive manager of the hospital. They have no other forms of supervision, so they are considered at a senior level. The following are the 3 sections of the questionnaire form distributed by the author of this paper:

- time- based balance/ imbalance

- Doing my best in my work entails a reduction of time devoted to my family.

- Long work hours mean that I am a good employee.

- My hospital adopts flexible timing policy to promote work/ life balance time.

- $\quad$ strain- based balance/ imbalance

- I feel stressed towards my family obligations.

- I feel stressed to prove that I am a good employee and a good family member.

- My hospital encourages a smooth balance work/ family life for me.

- behavior- based balance/ imbalance

- My work life interferes with my family life.

- Sometimes, I face a conflict with my hospital to balance my work/ life time.

○ My organization cares only about my work time.

The following is the reliability analysis for work- life balance/imbalance using Cronbach's alpha.

Table 2. Reliability Analysis for work- life balance/imbalance

\begin{tabular}{|c|c|c|}
\hline Scale name & $\begin{array}{c}\text { Number } \\
\text { of items }\end{array}$ & $\begin{array}{c}\text { Coefficient } \\
\text { alpha values }\end{array}$ \\
\hline Work- life balance/ imbalance & 9 & 0.871 \\
\hline Time- based balance/imbalance & 3 & 0.822 \\
\hline Strain-based balance/imbalance & 3 & 0.809 \\
\hline $\begin{array}{c}\text { Behavior- based } \\
\text { balance/imbalance }\end{array}$ & 3 & 0.702 \\
\hline
\end{tabular}

The following table (Table 3 ) shows the demographic variables of the respondents.
Table 3. Profile of the respondents

\begin{tabular}{|c|c|c|}
\hline $\begin{array}{c}\text { Demographic } \\
\text { Variables }\end{array}$ & Items & Count \\
\hline \multirow{2}{*}{ Gender } & Male & 0 \\
\hline & Female & 225 \\
\hline \multirow{7}{*}{ Age } & below 25 years & 19 \\
\hline & 26-30 years & 150 \\
\hline & $31-35$ years & 51 \\
\hline & $36-40$ years & 5 \\
\hline & $41-45$ years & 0 \\
\hline & $46-50$ years & 0 \\
\hline & More than 50 years & 0 \\
\hline \multirow{3}{*}{ Marital States } & Single & 70 \\
\hline & Married & 125 \\
\hline & Other & 30 \\
\hline \multirow{3}{*}{$\begin{array}{l}\text { Level of } \\
\text { Education }\end{array}$} & Bachelor & 15 \\
\hline & Bachelor + Diploma & 200 \\
\hline & Master & 10 \\
\hline \multirow{5}{*}{ Level of Income } & EGP 1200 & 0 \\
\hline & EGP 1300-2500 & 225 \\
\hline & EGP 2500-4000 & 0 \\
\hline & EGP 4000-5500 & 0 \\
\hline & Above 5500 & 0 \\
\hline \multirow{6}{*}{$\begin{array}{l}\text { Organizational } \\
\text { tenure }\end{array}$} & Less than 1 year & 5 \\
\hline & $1-3$ years & 20 \\
\hline & 4-6 years & 200 \\
\hline & $7-9$ years & 0 \\
\hline & 10-12 years & 0 \\
\hline & Above 15 years & 0 \\
\hline \multirow{2}{*}{ Religion } & Muslim & 200 \\
\hline & Christian & 25 \\
\hline \multirow{2}{*}{ Work Bases } & Full time & 225 \\
\hline & Part time & 0 \\
\hline
\end{tabular}

\section{RESULTS}

The main purpose of this research is to understand how much of the variation in time, strain and behavior- based balance/imbalance can be explained by responsible leadership dimensions (aggregate of virtues, stakeholder involvement, model of leader's role and principles of ethical values). The use of multiple regression analysis assists in understanding the unique contribution of each of the responsible leadership dimensions. However, using multiple regressions requires the following assumptions presented in Table 4.

Table 4.

\begin{tabular}{|c|c|}
\hline $\begin{array}{c}\text { Assumption } \\
\text { No. }\end{array}$ & Description \\
\hline $\begin{array}{c}\text { Assumption } \\
1\end{array}$ & $\begin{array}{c}\text { Independence of observation: There is no } \\
\text { autocorrelation }\end{array}$ \\
\hline $\begin{array}{c}\text { Assumption } \\
2\end{array}$ & $\begin{array}{c}\text { Linearity: There is a linear relationship between } \\
\text { the dependent variables and each of the } \\
\text { independent variables on the one hand, and the } \\
\text { dependent variables and the independent } \\
\text { variables collectively, on the other. }\end{array}$ \\
\hline $\begin{array}{c}\text { Assumption } \\
3\end{array}$ & $\begin{array}{c}\text { Homoscedasticity: variance along the line of } \\
\text { best remains similar as you move along the line }\end{array}$ \\
\hline $\begin{array}{c}\text { Assumption } \\
4\end{array}$ & $\begin{array}{c}\text { No multi-collinearity: When } 2 \text { or more } \\
\text { independent variables are highly correlated } \\
\text { with each other }\end{array}$ \\
\hline
\end{tabular}

For Assumption 1, the Durbin-Watson test, which is a measure of significant residual autocorrelation and ideally ranges39 
between 1.5 to 2.5 , is used and the results are as follows:

Table 5. Durbin-Watson test indicator values

\begin{tabular}{|c|c|}
\hline & Independent variables \\
\hline Dependent variables & $\begin{array}{l}\text { aggregates of virtues, } \\
\text { stakeholder } \\
\text { involvement, model of } \\
\text { leaders' role and } \\
\text { principles of ethical } \\
\text { values }\end{array}$ \\
\hline time- based balance/ imbalance & 1.854 \\
\hline strain- based balance/ imbalance & 1.739 \\
\hline behavior- based balance/ imbalance & 1.662 \\
\hline
\end{tabular}

For assumptions 2 and 3, a Chart Builder is used to determine whether there is a registered linear relationship between Work - life balance-imbalance (the dependent variables), Responsible Leadership aspects (aggregate of virtues, stakeholder involvement, model of leaders' role and principles of ethical values) collectively (the independent ones) or not. It is subsequently used to determine whether a linear relationship exists between the dependent variable and each of the independent variables, which can be achieved using partial regression plots between each of the independent variables and the dependent variable. The chart shows a linear relationship a matter that urges the use of hierarchical multiple regressions.

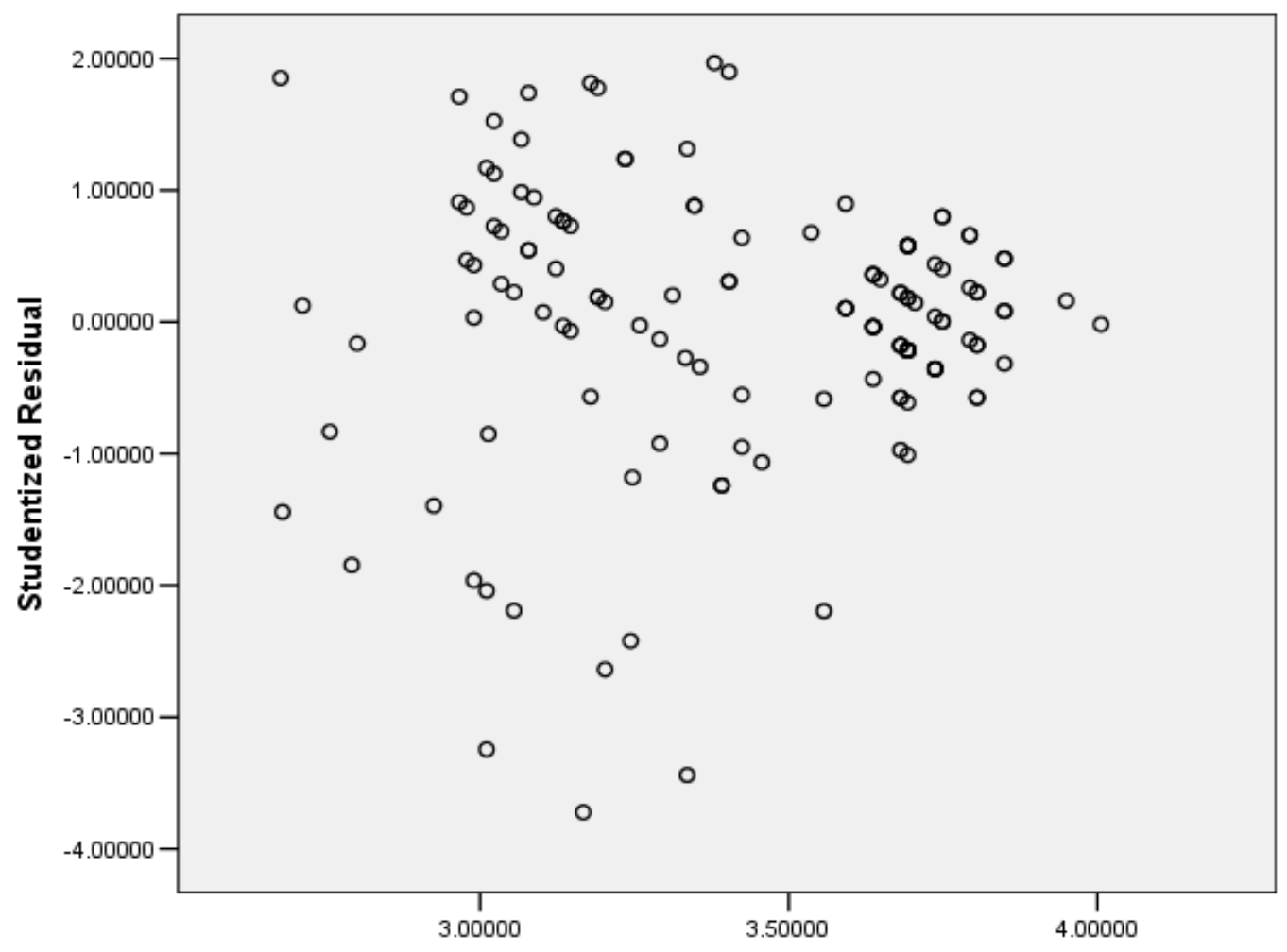

Unstandardized Predicted Value

Figure 1. The Chart Builder graph for the investigated relationship

Assumption 4 highlights the fact that any existence of multicollinearity, which occurs if two or more independent variables are highly correlated with each other, yields technical difficulties in adopting a multiple regression model. If tolerance values are less than 0.01 , the researcher cannot proceed with hierarchical multiple regressions, which is not the case here as indicated in Table 6.

Table 6. Correlation coefficient and tolerance between independent variables

\begin{tabular}{|c|c|c|}
\hline \multirow{2}{*}{} & \multicolumn{2}{|c|}{ Collinearity Statistics } \\
\cline { 2 - 3 } & Tolerance & VIF \\
\hline Model 1 & 1.000 & 1.000 \\
\hline Model 2 & .951 & 1.051 \\
\hline Model 3 & .874 & 1.144 \\
\hline Model 4 & .762 & 1.312 \\
\hline
\end{tabular}

Note: In Model 1, the constant variable is Aggregate of virtues. In Model 2, the constant variable is Aggregate of virtues and Stakeholder involvement. In Model 3, the constant variables are Aggregate of virtues, Stakeholder involvement and Model of leaders' role. In Model 4, the constant variables are Aggregate of virtues, Stakeholder involvement, Model of leaders' role and Principles of ethical values.

Testing the research hypotheses is necessary to validate of the hierarchical multiple regression analysis. In order to evaluate the regression models in the hierarchical multiple regressions in the present study, four models were used. In the first model, the independent variable is Aggregate of virtues and the 3 elements of Work-life balance/imbalance will be used as separated dependent variables. In the second model, the independent variables are Aggregate of virtues and Stakeholder involvement. Notably, the second Model is not a completely separate model but a variation of Model 1 with one variable added. In the third model, the independent variables are Aggregate of virtues, Stakeholder involvement and Model of leaders' role. And finally in the fourth model, the independent variables are Aggregate of virtues, Stakeholder involvement, Model of leaders' role and Principles of ethical values.

Each model is a standard multiple regression procedure with the variables in that model entered simultaneously. Therefore, 40 
Table 7. Summary of the Regression Analyses of the Models

\begin{tabular}{|c|c|c|c|c|c|c|c|c|c|c|}
\hline & $\sum_{\bar{c}}^{\bar{c}}$ & $\mathrm{R}$ & R Square & $\begin{array}{l}\text { Adjusted } \\
\text { R Square }\end{array}$ & $\begin{array}{l}\text { Std. Error } \\
\text { of the } \\
\text { Estimate }\end{array}$ & $\begin{array}{l}\text { R Square } \\
\text { Change }\end{array}$ & $\mathrm{F}$ & df1 & $\mathrm{df} 2$ & $\begin{array}{l}\text { Sig. F } \\
\text { Change }\end{array}$ \\
\hline \multirow{4}{*}{ D1 } & 1 & .653 & .613 & .619 & 7.20155 & 0.613 & 11.994 & 1 & 223 & .000 \\
\hline & 2 & .769 & .725 & .687 & 4.19765 & 0.112 & 41.496 & 1 & 222 & .000 \\
\hline & 3 & .797 & .763 & .752 & 7.19238 & 0.038 & 49.230 & 1 & 221 & .003 \\
\hline & 4 & .833 & .804 & .780 & 7.18390 & 0.041 & 52.469 & 1 & 220 & .000 \\
\hline \multirow{4}{*}{ D2 } & 1 & .067 & .004 & .004 & .20268 & .004 & .507 & 1 & 223 & .067 \\
\hline & 2 & .711 & .692 & .676 & 3.20277 & .692 & 35.900 & 1 & 222 & .000 \\
\hline & 3 & .834 & .795 & .762 & 2.14560 & .103 & 40.219 & 1 & 221 & .000 \\
\hline & 4 & .897 & .850 & .843 & 7.13214 & .055 & 42.757 & 1 & 220 & .000 \\
\hline \multirow{4}{*}{ D3 } & 1 & .667 & .624 & .604 & 8.20268 & .624 & 20.507 & 1 & 223 & .000 \\
\hline & 2 & .741 & .720 & .695 & 5.20277 & .096 & 34.900 & 1 & 222 & .000 \\
\hline & 3 & .794 & .785 & .762 & 10.14560 & .062 & 43.219 & 1 & 221 & .000 \\
\hline & 4 & .827 & .808 & .783 & 9.13214 & .023 & 50.757 & 1 & 220 & .767 \\
\hline
\end{tabular}

Note: D1, D2 and D3 are the dependent variables which are the three aspects of Work-life balance/imbalance. D1 = timebased balance/ imbalance; D2 = strain- based balance/ imbalance; D3 = behavior- based balance/ imbalance variable, $\mathrm{R}^{2}$ increases by .038 (the variance explained increased by $3.8 \%)$, and this increase is statistically significant $(\mathrm{p}<.0005)$. In sum, the addition of Model of leaders' role to the prediction of Aggregate of virtues (Model 3) has led to a statistically significant increase in $\mathrm{R}^{2}$ of .038 and $\mathrm{F}(1,221)=49.230, \mathrm{p}<$ .0005 .

With regards to the last Model (4), where Principles of ethical values is added as an independent variable, $\mathrm{R}^{2}$ increases by .0 .041 (the variance explained has increased by $4.1 \%$ ), and this increase is statistically significant $(p<.0005)$. Thus, the addition of Principles of ethical values to the prediction of Aggregate of virtues (Model 4) has brought about a statistically significant increase in $\mathrm{R}^{2}$ of .041 and $\mathrm{F}(1,220)=52.469, \mathrm{p}<$ .0005 .

In the case of the dependent variable Strain- based balance/ imbalance in Model 1, in which Aggregate of virtues stands alone, there is no statistical significance of $p<0.005$. Due to the inclusion of Stakeholder involvement as an additional independent variable, $\mathrm{R}^{2}$ is .692 , and this increase is statistically significant $(p<.0005)$ and $F=35.900$. In other words, Stakeholder involvement adds statistical significance to the prediction of Aggregate of virtues. In the third Model where Model of leaders' role is added as independent variable, $\mathrm{R}^{2}$ has increased by .103 (the variance explained increased by $10.3 \%)$, and this increase is statistically significant $(\mathrm{p}<.0005)$. Therefore, the addition of Model of leaders' role to the prediction of Aggregate of virtues (Model 3) has resulted in a statistically significant increase in $\mathrm{R}^{2}$ of .103 and $\mathrm{F}(1,221)=$ $40.2190, \mathrm{p}<.0005$.

Concerning the last Model (4) where Principles of ethical values is added as independent variable, $\mathrm{R}^{2}$ has increased by
.0 .055 (the variance explained increased by $5.5 \%$ ), and this increase is statistically significant $(p<.0005)$. Hence, the addition of Principles of ethical values to the prediction of Aggregate of virtues (Model 4) has led to a statistically significant increase in $\mathrm{R}^{2}$ of .055 and $\mathrm{F}(1,220)=42.757, \mathrm{p}<$ .0005 .

In the case of the dependent variable Behavior- based balance/ imbalance in Model 1, in which Aggregate of virtues alone is the independent variable, $\mathrm{R}$ is 0.624 , with statistical significance of $p<0.005$. Due to the inclusion of Stakeholder involvement as an additional independent variable, $\mathrm{R}^{2}$ has increased by .96 (the variance explained increased by $9.6 \%$ ), and this increase is statistically significant $(\mathrm{p}<.0005)$ and $\mathrm{F}$ increased to 34.900. In other words, Stakeholder involvement adds statistical significance to the prediction of Aggregate of virtues. As a result, the addition of Stakeholder involvement to the prediction of Aggregate of virtues (Model 2) has also led to a statistically significant increase in $\mathrm{R}^{2}$ of .096 and $\mathrm{F}(1,222)=$ $34.900, \mathrm{p}<.0005$.

In the third Model where Model of leaders' role is added as independent variable, $\mathrm{R}^{2}$ has increased by .062 (the variance explained increased by $6.2 \%$ ), and this increase is statistically significant $(\mathrm{p}<.0005)$. In summary, the addition of Model of leaders' role to the prediction of Aggregate of virtues (Model 3 ) brought about a statistically significant increase in $R^{2}$ of .062 and $\mathrm{F}(1,221)=43.219, \mathrm{p}<.0005$.

In the last Model (4) where Principles of ethical values is added as independent variable, $\mathrm{R}^{2}$ has increased by 0.023 (the variance explained increased by $2.3 \%$ ), and this increase is statistically significant $(p<.0005)$. As such, the addition of Principles of ethical values to the prediction of Aggregate of virtues (Model 4) has resulted in a statistically significant increase in $\mathrm{R}^{2}$ of .023 and $\mathrm{F}(1,220)=50.757, \mathrm{p}<.0005$. 
Table 8. Hierarchical Multiple Regression predicting Time- based balance/ imbalance as element of Work - life balance/imbalance from Aggregate of virtues, Stakeholder involvement, Model of leaders' role and Principles of ethical values

\begin{tabular}{|c|c|c|c|c|c|c|c|c|}
\hline & & & $\mathrm{B}$ & $\beta$ & $\mathrm{R}^{2}$ & $\mathrm{~F}$ & $\Delta \mathrm{R}^{2}$ & $\Delta \mathrm{F}$ \\
\hline \multirow{14}{*}{ D1 } & \multirow{2}{*}{ Model 1} & (Constant) & 2.090 & & .613 & 11.994 & 0.613 & 11.994 \\
\hline & & Aggregate of virtues & .425 & .388 & . & & & \\
\hline & \multirow{3}{*}{ Model 2} & (Constant) & 2.450 & & 725 & 30.425 & 0.687 & 41.496 \\
\hline & & Aggregate of virtues & .405 & .368 & & & & \\
\hline & & Stakeholder involvement & .232 & .199 & & & & \\
\hline & \multirow{4}{*}{ Model 3} & (Constant) & 3.151 & & .763 & 35.003 & 0.752 & 49.230 \\
\hline & & Aggregate of virtues & .435 & .409 & & & & \\
\hline & & Stakeholder involvement & .367 & .309 & & & & \\
\hline & & Model of leaders' role & .250 & .193 & & & & \\
\hline & \multirow{5}{*}{ Model 4} & (Constant) & 2.115 & & .804 & 45.054 & 0.780 & 52.469 \\
\hline & & Aggregate of virtues & .483 & .440 & & & & \\
\hline & & Stakeholder involvement & .373 & .324 & & & & \\
\hline & & Model of leaders' role & .268 & .219 & & & & \\
\hline & & Principles of ethical values & .177 & .122 & & & & \\
\hline
\end{tabular}

Note: $\mathrm{N}=225 ; \mathrm{p}<0.05$

Table 9. Hierarchical Multiple Regression predicting Strain-based balance/ imbalance as element of Work-life balance/imbalance from Aggregate of virtues, Stakeholder involvement, Model of leaders' role and Principles of ethical values.

\begin{tabular}{|c|c|c|c|c|c|c|c|c|}
\hline & & & $\mathrm{B}$ & $\beta$ & $\mathrm{R}^{2}$ & $\mathrm{~F}$ & $\Delta \mathrm{R}^{2}$ & $\Delta \mathrm{F}$ \\
\hline \multirow{14}{*}{ D2 } & \multirow{2}{*}{ Model 1} & (Constant) & 4.403 & & 0.004 & 0.507 & .004 & 0.507 \\
\hline & & Aggregate of virtues & 0.027 & 0.067 & & & & \\
\hline & \multirow{3}{*}{ Model 2} & (Constant) & 4.668 & & 0.692 & 25.703 & 0.676 & 35.900 \\
\hline & & Aggregate of virtues & 0.036 & 0.027 & & & & \\
\hline & & Stakeholder involvement & 0.496 & 0.391 & & & & \\
\hline & \multirow{4}{*}{ Model 3} & (Constant) & 5.023 & & 0.795 & 36.316 & 0.762 & 40.219 \\
\hline & & Aggregate of virtues & 0.122 & 0.098 & & & & \\
\hline & & Stakeholder involvement & 0.497 & 0.382 & & & & \\
\hline & & Model of leaders' role & 0.427 & 0.388 & & & & \\
\hline & \multirow{5}{*}{ Model 4} & (Constant) & 4.840 & & 0.850 & 39.255 & 0.843 & 42.757 \\
\hline & & Aggregate of virtues & 0.171 & 0.073 & & & & \\
\hline & & Stakeholder involvement & 0.391 & 0.376 & & & & \\
\hline & & Model of leaders' role & 0.408 & 0.386 & & & & \\
\hline & & Principles of ethical values & 0.387 & 0.327 & & & & \\
\hline
\end{tabular}

Note: $\mathrm{N}=225 ; \mathrm{p}<0.05$

Table 10. Hierarchical Multiple Regression predicting Behavior- based balance/ imbalance as element of Work - life balance/imbalance from Aggregate of virtues, Stakeholder involvement, Model of leaders' role and Principles of ethical values.

\begin{tabular}{|c|c|c|c|c|c|c|c|c|}
\hline & & & $\mathrm{B}$ & $\beta$ & $\mathrm{R}^{2}$ & $\mathrm{~F}$ & $\Delta \mathrm{R}^{2}$ & $\Delta \mathrm{F}$ \\
\hline \multirow{14}{*}{ D3 } & \multirow{2}{*}{ Model 1} & (Constant) & 2.477 & & 0.624 & 20.507 & 0.604 & 20.507 \\
\hline & & Aggregate of virtues & 0.196 & 0.165 & & & & \\
\hline & \multirow{3}{*}{ Model 2} & (Constant) & 2.724 & & 0.720 & 30.778 & 0.695 & 34.900 \\
\hline & & Aggregate of virtues & 0.288 & 0.252 & & & & \\
\hline & & Stakeholder involvement & 0.390 & 0.260 & & & & \\
\hline & \multirow{4}{*}{ Model 3} & (Constant) & 4.558 & & 0.785 & 37.187 & 0.762 & 43.219 \\
\hline & & Aggregate of virtues & 0.285 & 0.177 & & & & \\
\hline & & Stakeholder involvement & 0.376 & 0.251 & & & & \\
\hline & & Model of leaders' role & 0.426 & 0.381 & & & & \\
\hline & \multirow{5}{*}{ Model 4} & (Constant) & 3.586 & & 0.808 & 45.870 & 0.783 & 50.757 \\
\hline & & Aggregate of virtues & 0.214 & 0.197 & & & & \\
\hline & & Stakeholder involvement & 0.352 & 0.235 & & & & \\
\hline & & Model of leaders' role & 0.299 & 0.181 & & & & \\
\hline & & Principles of ethical values & 0.431 & 0.391 & & & & \\
\hline
\end{tabular}


- Hierarchical multiple regressions are run to determine if the addition of three more variables: Stakeholder involvement, Model of leaders' role, Principles of ethical values as part of Responsible Leadership would improve the prediction of Time- based balance/ imbalance over and above Aggregate of virtues. The full model of Responsible Leadership and Work-life balance/imbalance for predicting Time- based balancel imbalance (Model 4) is found to be statistically significant $-\mathrm{R}^{2}=0.804, \mathrm{~F}(1,220)$ $=45.054 .433, \mathrm{p}<.0005$, and adjusted $\mathrm{R}^{2}=0.780$.

- Hierarchical multiple regressions are run to determine if the addition of Stakeholder involvement, Model of leaders' role, Principles of ethical values as part of Responsible Leadership would improve the prediction of Strain- based balancel imbalance over and above Aggregate of virtues, as Aggregate of virtues is not statistically significant for this model. The full model of Responsible Leadership and Work-life balance/imbalance for predicting Strain- based balance/ imbalance (Model 4) is statistically significant $-\mathrm{R}^{2}=0.850 \mathrm{~F}(1,220)=39.255$, $\mathrm{p}<.0005$; adjusted $\mathrm{R}^{2}=0.843$.

- Hierarchical multiple regressions are run to determine whether the addition of involvement, Model of leaders' role, Principles of ethical values as part of Responsible Leadership - would improve the prediction of Behaviorbased balancel imbalance over and above Aggregate of virtues. The full model of Responsible Leadership and Work-life balance/imbalance for predicting Behaviorbased balancel imbalance (Model 4) is statistically significant $-\mathrm{R}^{2}=0.808 \mathrm{~F}(1,220)=45.870, \mathrm{p}<.0005$; adjusted $\mathrm{R}^{2}=0.783$.

\section{DISCUSSION}

The importance of this topic pertains to the recent changes in Egyptian labor market which occupy a tremendous space in not only in Egyptian social discourse but also in various international social media outlets. The Egyptian labor market in which men used to have superiority, authority and domination has lately witnessed an increasing active participation of Egyptian women especially with the increasing number of success stories of Egyptian female managers, entrepreneurs and executives in both public and private organizations (Mousa \& Abdelgaffar, 2017). It is obvious that masculinity-oriented tendency, uncertain work environment, changing job roles, and social class discrimination that many Egyptians face did not curb Egyptian women from penetrating the labor market there.

The research unit of this current study is female pharmacists, and the research place is public hospitals in Menoufia province in Egypt. This study was inspired by the results of Mousa (2017) which convey the suffering experienced by Egyptian female nurses working in the Egyptian public health sector. The interviews included in this study assert that Egyptian female nurses struggle due to long working hours, male domination, and work overload because of their small number and/or the desire to prove themselves in a male-dominant society. This study is mostly about discrimination and managing cultural diversity in Egyptian public health sector and it touches on the challenges of balancing work and nonwork activities and time. In the present study, the author found it a very pioneering attempt to address the marginalization of females in Egyptian public sector. The present study, thus, focuses on investigating the effect of responsible leadership dimensions (aggregate of virtues, stakeholder engagement, and leader-followers model) on three forms of work-life balance/imbalance among the female pharmacists in Menoufia public hospitals (Egypt).

The first hypothesis of the present study is whether responsible leadership dimensions () affect time based balance/ imbalance, and the results show that only aggregate virtue has a significant effect on time-based balance/imbalance. This result seems logic because the main philosophy of aggregation of virtue is to urge organizational leaders to fulfill their socio-political responsibility towards their surrounding environment. This result is a valid contribution to the general public with respect to areas such as education, health, and supporting people with disabilities. In this case study, female pharmacists, as reporting in the conducted interviews, work 12 hours a day, and thus cannot be expected to manage their non-work activities and cannot devote time for discussing or promoting their hospitals' care towards public well-being, which is a main aim of aggregate virtue.

The same can be said about the results of testing the second hypothesis which showed that all dimensions of responsible leadership affect strain-based balance/imbalance except the aggregate of virtues. This result sounds logic also as what a hospital or workplace is doing for others in its surroundings might not be an urgent concern for female pharmacists who mainly struggle to find time for their social and family obligations. The results of the third hypothesis indicate that the aggregate of virtue is not considered a significant statistical predictor of female pharmacists' behavior-based balance/imbalance. Consequently, neither would the hospital be able to undertake its social responsibilities or not would it be able to support female pharmacists' tendency and subsequently attempts to balance their work/non-work activities.

The previous results reflect that female pharmacists cannot be considered an active participator in calling for or contributing to the general well-being of their surrounding stakeholders without having the means, resources and authority required to encourage their workplace to handle its responsibilities as indicated by Cameron (2011). Additionally, female pharmacist will not think about others without having attained their psychological self-actualization first. Such psychological selfactualization involves having reasonable work hours, relevant level of performance, sufficient days off and vacations, and mostly persuasive open work-related communications as well. Given the previous results, the author of the present study unintentionally found himself raising the questions concerning when and to what extent female pharmacists should motivate their leaders to undertake their societal objectives and whether there is any opportunity in such climate of stress to think about public-related aspects.

It is needless to say that the results of the present study encourage management academicians and practitioners to look for the main conditions required for the effective adoption of responsible leadership in the Egyptian public context. Moreover, the same can be said about work-life balance which is considered by Andersen (2000) as a priority for countries that seek welfare for its citizens. Accordingly, one could ask about the efficacy of the current socio-political climate that Egypt is witnessing and the role of this climate in motivating public organizations like hospitals to address the forms of work-life balance/imbalance in its human resources management agenda.

\section{IMPLICATIONS FOR MANAGERS}

Apparently, employees' attitude towards societal integration 43 
and subsequently citizenship would not be attained without a feeling of fairness and inclusion in their workplace. Many studies (e.g. Pless, 2007, Mousa, 2017) have discussed the importance of equal employment opportunity approach in recruiting employees. However, the approach of equal employment should expand to cover assisting employees, especially females, in balancing their work/ non-work activities. In Egypt, the view of seeing the man as the sole breadwinner of the family should be shifted to reflect the current existence of woman in workplace. Accordingly, organizational elites should create a mechanism to consider female work-life balance as a part of Egyptian public policy. Consequently, public organizations like hospitals have to responsively treat women pharmacists as a main part of stakeholders whom are in need for flexible work hours, active participation in decision making, and clear empowerment in workplace. Logically, previous needs of female pharmacist are included within the scope of responsible leadership dimensions. Unfortunately, much uncertainty exists concerning their real adoption in the Egyptian public health organizations. In fact, it is the time for the whole society to reevaluate the current style of leadership and its implications in aspects such as female work-life balance in different organizational settings.

\section{CONCLUSION}

In conclusion, this study investigates whether responsible leadership dimensions can affect female pharmacists' worklife balance/ imbalance in Menoufia province public hospitals in Egypt. This research maybe subject to criticism because it focuses only on a single Egyptian province - a matter that does not give way to a variety of views. Furthermore, the author overlooked some moderating variables such as the pharmacists' engagement, inclusion, job autonomy and so on.

For future studies, the author suggests the same propositions be tested with physicians, nurses, and other categories of employees in Egyptian public hospitals. Moreover, a qualitative interdisciplinary study is urgently needed to identify the existence of responsible leadership in the Egyptian public health sector. Furthermore, a multi-disciplinary study for scholars from fields likes organizational psychology, organizational communication, human resources management, public administration, public policy and cultural diversity management is also needed to propose a mechanism for balancing female pharmacists' work/ non-work activities and to find solutions for the double amount of time and effort required from them in performing their job roles. Finally the same hypotheses of this study should be tested in other private and non-for profits Egyptian organizations to explore the female work/ life situations there as well.

\section{REFERENCES}

1. Alas, R. \& Mousa, M. (2016). Cultural diversity and business schools' curricula: a case from Egypt, Problems and perspectives in management, Vol. 14 No. 2, pp 130137.

2. Antunes, A. and Franco, M. (2016), "How people in organizations make sense of responsible leadership practices- Multiple case studies", Leadership \& Organization Development Journal, Vol. 37 No. 1, pp. 126-152.

3. Anxo, D.; Franz, C. \& Kummerling, A. (2013). Working in time and work- life balance in a life course perspective, European foundation for the improvement of living and working conditions, Dublin.
4. Avgar, A. C., Givans, R. K. \& Liu, M. (2011). A balancing act: work- life balance and multiple stakeholder outcomes in hospitals, British journal of industrial relations, Vol. 49 No. 4, pp. 717- 741.

5. Avram, D.O. and Kuhne, S. (2008), Implementing responsible business behavior from a strategic management perspective: Developing a framework for Austrian SMEs, Journal of Business Ethics, Vol. 82 No. 2, pp. 463-475.

6. Bonoli, G. (2005). The politics of the new social policies: providing coverage against new social risks in mature welfare states, Policy and politics, Vol. 33 No. 3, pp.431449.

7. Brown, R.; Charnsangavej, T.; Kenough, K. A.; Newan, M. L. and Rentfrow, P. (2000), putting the affirm into affirmative action: preferential selection and academic performance, Journal of Personality and Social Psychology 79 (5). Pp. 736- 747.

8. Cameron, K. (2011), "Responsible leadership as virtuous leadership", Journal of Business Ethics, Vol. 98 No. 1, pp. 25-35.

9. Carlson, D.S.; Witt, L.A.; Zivnuska, S. (2009). Is workfamily balance more than conflict and enrichment? Human relations, Vol. 62 No. 10, pp. 1459- 1468.

10. Carnicer, M.; Sanchez, A.M.; Perez, M.P. \& Vela Jimenez, M.J. (2003). Gender differences at mobility: analysis of job and work- family factors, Women in management review, Vol. 18 No. 4, pp. 199- 219.

11. Carrasco, I. (2007), "Corporate social responsibility, values and cooperation", International Advances in Economic Research, Vol. 13 No. 4, pp. 454-460.

12. Cegarra- Leiva, D.; Sanchez- Vidal, M. E. \& CegarraNavarro, J. G. (2012). Understanding the link between work life balance practices and organizational outcomes in SMEs, Personnel review, Vol. 41 No. 3, pp. 359-379.

13. Ciculla, J.B. (2004), "Ethics and leadership effectiveness", in Antonakis, J., Cianciola, A.T. and Sternberg, R.J (Eds), The Nature of Leadership, Sage Publications, Thousand Oaks, CA, PP. 302-328.

14. Clark, S. C. (2000). Work/ family border theory: a new theory of work/ family balance, Human relations, Vol. 53 No. 6, pp. 747-770.

15. Cunha, M., Rego, A. and Cunha, R. (2007), Positive Organizations, Dom Quixote, Lisbon.

16. De Hoogh, A.H. and Den Hartog, D.N. (2008), "Ethical and despotic leadership, relationships with leader's social responsibility, top management team effectiveness and subordinates' optimism: a multi- method study", The Leadership Quarterly, Vol. 19 No. 3, pp. 297-314.

17. Drew, E. \& Daverth, G. (2009). Living together... or working to live? The role of managers in creating worklife balance in Ireland, ICTU Briefing Paper, Dublin, pp. $1-27$.

18. Drew, E. \& Murtagh, E. M. (2005). Work/ life balance: senior management champions or laggards?, women in management review, Vol. 20 No. 4, pp.262- 278.

19. Drew, E., Humphrey, P. \& Murphy, C. (2003). Off the treadmill- achieving work/ life balance, the national framework committee for work/ life balance policies.

20. Earley, P. C. (1989). Social loafing and collectivism: a comparison of the united states and the people's republic of china, Administrative sciences quarterly, Vol. 34 No. 4 , pp. 565-581.

21. Eikhof, D. R.; Warhust, C. \& Haunschild, A. (2007). Introduction: what work? What life? What balnce? Critical reflections on the work- life balance debate, 44 
Employee relations, Vol. 29 No. 4, pp. 325-333.

22. Elloy, D. F. \& Smith, C. R. (2003). Patterns of stress, work- family conflict, role conflict, role ambiguity and overload among dual- career and single- career couples: an Australian study, cross cultural management, Vol. 10 No. 1, pp. 55-66.

23. Emslie, C. \& Hunt, K. (2009). Live to work or work to live? A qualitative study of gender and work- life balance among men and women in mid- life, Gender, work and organization, Vol. 16 No. 1, pp. 151- 172.

24. Erkutlu, H. \& Chafra, J. (2016). Benevolent leadership and psychological well- being: the moderating effects of psychological safety and psychological contract breach. Leadership \& organization development journal, Vol. 37 No. 3, pp. 369- 386.

25. Eva,N. \& Sendjaya, S. (2013). Creating future leaders: an examination of youth leadership development in Australia, Education and training, Vol. 55 No. 6, pp. 584-598.

26. Fishbein, M. \& Ajzen, I. (1975). Belief, attitude, intention and behavior: an introduction to theory and research, Addison- weley pub. Co., Ontario.

27. Frone, M. R.; Yardley, J. K. \& Markel, K. S. (1997). Developing and testing an integrative model of workfamily interface, Journal of vocational behavior, Vol. 50, pp. $145-167$.

28. Fu, C. \& Shaffer, M. (2001). The tug of work and family: direct and indirect domain- specific determinants of family interference with work and work interference with family, personnel review, Vol. 30 No. 1, pp. 502-522.

29. Gregory, A.; Milner, S. \& Windebank, J. (2013). Worklife balance in times of economic crisis and austerity, International journal of sociology and social policy, Vol. 33 No. 9/10, pp. 528-541.

30. Harr, J. \& Spell, C. (2004). Programme knowledge and value of work. Family practice and organizational commitment, The international journal of human resources management, Vol. 15 No. 6.

31. Hennig, M., Gaterman, D. \& Hagglund, A. E. (2012). Pros and cons of family of family policies for mother's labour market participation, international journal of sociology and social policy, Vol. 32 No. 9/10, pp. 502- 512.

32. Hofstede, G. \& Hofstede, G.J. (2005). Cultures and organizations: software of the mind. McGraw Hill.

33. Holt, R. (2006), Principles and practice: Rhetoric and the moral character of managers, Human relations, Vol. 59 No. 2, pp. 1659-1680.

34. Hymavathi, Ch. L.; Kasarabada, A. \& Avadhanam, S. (2015). Demonstrating responsible leadership at SOS Villages-A real case, International journal on leadership, Vol. 3 No. 2, pp.1-6.

35. Inglehart, R. (2008), "changing values among western publics from 1970 to 2006", West European Politics, Vol. 31 No1-2, pp. 130-146.

36. Kim, H. K. (2014). Work- life balance and employees' performance: the mediating role of affective commitment, Global business and management research: An international journal, Vol. 6 No. 1, pp. 37-51.

37. Kim, S. M. (2012). A study on women resources utilization: introduction of work- life balance policy, unpublished master's thesis, Keimyung university, Korea.

38. Lee, Y. H. (2005). The effect of work- life practices on the job pursuit intentions, unpublished master's thesis, Joongang university, Korea.

39. Lim, D. H.; Song, J. H. \& Choi, M. (2012). Work- family interface: effect of enrichment and conflict on job performance of Korean workers, Journal of management and organization, Vol. 18 No. 3, pp. 383-397.

40. Maak, T. and Pless, N. M. (2006), Responsible leadership in a stakeholder society- A relational perspective, Journal of Business Ethics, Vol. 66 No. 1, Pp. 99- 115.

41. Maak, T. and Pless, N. M. (2009), Business leaders as citizens of the world. Advancing humanism on a global scale, Journal of Business Ethics, Vol. 88 No. 3, Pp. 537550 .

42. Morland, M.P. (2015), Philosophical assumptions undermining responsible management education, Journal of Management Development, Vol. 34 No. 1, pp. 61-75.

43. Mousa, M. \& Abdelgaffar, H. (2017). A float in uncertainty and cynicism: an experience from Egypt, Journal of commerce \& management thought, Vol. 8 No. 3.

44. Mousa, M. \& Abdelgaffar, H.A. (2017). A float over uncertainty and cynicism: an experience from Egypt. Journal of commerce and management thought 8 (3). Pp 508- 530.

45. Mousa, M. \& Alas, R. (2016). Cultural diversity and organizational commitment: A study on teachers of primary public schools in Menoufia (Egypt). International Business Research 9 (7). Pp. 154-163.

46. Mousa, M. \& Alas, R. (2016). Uncertainty and organizational commitment: a study on primary public schools' teachers in Menoufia (Egypt). European Journal of Business and Management 8 (20), 38- 47.

47. Mousa, M. (2017). Clouds over Egypt: Culture Traits and Organizational Commitment in Public Education. International journal of education and management studies 7 (2).Pp 251-258

48. Mousa, M. (2017). How do nurses perceive their cultural diversity? An exploratory case study. African journal of business management 11 (17). Pp 446-455.

49. Murphy, F. \& Doherty, L. (2011). The experience of work life balance for Irish senior managers, Equality, Diversity and Inclusion: An international Journal, Vol. 30 No. 4, pp. 252-277.

50. Nelson, D. L.; Quick, J. C.; Hitt, M. A. \& Moesel, D. (1990). Politics, lack of career progress and work/ home conflict: stress and strain for working women, Sex roles, Vol. 23 No. 3/4, pp. 169- 185.

51. Nonet, G., Kassel, K. and Meijs, L. (2016), "Understanding responsible management: Emerging themes and variations from European business school programs", Journal of Business Ethics, Vol. 139, pp.717736.

52. Parkes, L. P. \& Langford, P. H. (2008). Work- life balance or work- life alignment? A test of the importance of worklife balance for employee engagement and intention to stay in organizations, journal of management and organization, Vol. 14 No. 3, pp. 267- 284.

53. Pless, N. M. \& Maak, T. (2011). Responsible leadership: Pathways to the future, journal of business ethics, vol. 98, pp. 3-13.

54. Pless, N. M., Maak, T. and Waldman, D. A. (2012), "Different approaches toward doing the right thing: mapping the responsibility orientations of leaders", Asia Pacific Journal of Management, Vol. 26 No. 4, pp. 451465.

55. Pless, N.M. (2007), "Understanding responsible leadership: role identity and motivational drivers", Journal of Business Ethics, Vol. 74 No. 4, pp. 437-456.

56. Preez, R. D. \& Zyl, L. T. V. (2015). Toward the development of a corporate social responsibility 45 
leadership questionnaire: an adaptation of the LB1-2, SA journal of industrial psychology, Vol. 41 No. 1, pp. 1- 18.

57. Sharma, S.; Parmar, J. S. \& Chauhan, S. S. (2016). Workrelated variables and work- life balance - A study on nurses in government hospitals of himachal Pradesh, Productivity, Vol. 57 No. 3, pp. 286- 292.

58. Sheokand, K. S. \& Priyanka. (2013). Work life balance: an overview of Indian companies: international journal of research in commerce and management, Vol. 4 No. 1, pp. 138- 143.

59. Tran, D. M.; Fallon, W. \& Vickers, M. H. (2016). Leadership in Vietnamese state owned enterprises (SOEs) exploring multi- stakeholder perceptions- a qualitative study, Asia pacific journal of business administration, Vol. 8 No. 1, pp. 21-36.
60. Voegtlin, C. (2011), "Development of a scale measuring discursive responsible leadership", Journal of Business Ethics, Vol. 98 No. 1, pp. 57-73.

61. Wade, M. (2006), Developing leaders for sustainable business. IN T. Maak \& N. M. Pless (Eds.), Responsible Leadership (Pp. 227- 244). London: Routledge.

62. Waldman, D. A. and Galvin, B. M. (2008), Alternative perspectives of responsible leadership, Organizational Dynamics, Vol. 37 No. 4, Pp. 327-341.

63. Waldman, D. A. and Siegel, D. (2008), Defining the socially responsible leader, The Leadership Quarterly, Vol 19 No 1, Pp. 117-131.

64. Wang, S.; Huang, W.; Gao, Y.; Ansett, S. and Xu, S. (2015), Can socially responsible leaders drive Chinese firm performance?, Leadership \& Organization Development Journal, Vol. 36 No. 4, pp. 435-450. 